\title{
Immunophenotyping of leukocytes in bovine placenta
}

\section{Imunofenotipagem de leucócitos na placenta bovina}

Thais Martins CHUCRI ${ }^{1,2,3}$; Janaína Munuera MONTEIRO ${ }^{1}$; Ana Rita de LIMA $^{4}$; Paula Andrea de Santis BASTOS ${ }^{2,3}$; Vanessa Aparecida Feijó de SOUZA², José Roberto Kfoury JÚNIOR ${ }^{1}$

\footnotetext{
${ }^{1}$ Universidade de São Paulo, Faculdade de Medicina Veterinária, Departamento de Cirurgia, São Paulo - SP, Brazil ${ }^{2}$ Centro Universitário das Faculdades Metropolitanas Unidas, Faculdade de Medicina Veterinária, São Paulo - SP, Brazil ${ }^{3}$ Universidade Metropolitana de Santos, Faculdade de Medicina Veterinária, Santos - SP, Brazil

${ }^{4}$ Universidade Federal Rural da Amazônia, Laboratório de Pesquisa Morfológica Animal, Belém - PA, Brazil
}

\begin{abstract}
Lymphocytes and macrophages are the main white cells involved in fetal-maternal tolerance. Little is known about these leukocytes in bovine placenta, such as the quantity and location of these cells. Thus, the objective of this study was to identify lymphocyte and macrophage populations in bovine placenta using specific markers and flow cytometry. This study analyzed samples of placentomes and intercaruncular regions of cows in the three quarters of pregnancy. In the placentomes, during the first quarter of pregnancy, mean percentage of labeled CD3+ cells was 2.34\%; CD $8+, 1.28 \%$; CD14+, 1.66\%; and CD335+, 0.96\%. For the intercaruncular region, percentage of CD3+ cells was $0.71 \%$; $\mathrm{CD} 8+, 1.63 \% ; \mathrm{CD} 14+, 2.81 \%$; and $\mathrm{CD} 335+, 2.81 \%$. In the second quarter, placentomes showed $0.94 \%$ $\mathrm{CD} 3+$ cells; $0.77 \% \mathrm{CD} 8+; 0.72 \% \mathrm{CD} 14+$; and $0.51 \% \mathrm{CD} 335+$. In the intercaruncular region, percentage of labeled CD3+ cells was $0.50 \%$; CD8+, $1.81 \%$; CD14+, 2.64\%; and CD335+, $0.51 \%$. In the third quarter, placentomes showed labeling of $0.88 \% \mathrm{CD} 3+; 0.66 \% \mathrm{CD} 8+; 1.06 \% \mathrm{CD} 14+$; and $0.74 \% \mathrm{CD} 335+$ cells. In the intercaruncular region, percentage of labeled CD3+ cells was $0.19 \%$; CD8+, 2.23\%; CD14+, 2.43\%; and CD335+, 0.16\%. The results showed that there was a greater immunomarking of leukocytes $\mathrm{CD} 3+$ and $\mathrm{CD} 335+$ in the placentome when compared to the intercaruncular region during the third trimester. It can be concluded that leukocytes populations in bovine placenta is reduced, probably because of the syndesmochorial characteristic of bovine placenta. This represents a significant barrier for the immunological system of the mother, sharply decreasing the exposure of the conceptus to the mother's immune system.
\end{abstract}

Keywords: Placentome. Intercaruncular region. Immunology. Maternal-fetal tolerance.

\section{Resumo}

Linfócitos e macrófagos são os principais leucócitos envolvidos na tolerância materno-fetal. Pouco se sabe sobre esses leucócitos na placenta bovina, como por exemplo, a quantidade e localização dessas células. Assim, o objetivo desse estudo foi identificar populações de linfócitos e macrófagos na placenta bovina utilizando marcadores específicos e citometria de fluxo. Este estudo analisou amostras de placentônios da região intercaruncular de bovinos nos três trimestres da gestação. No primeiro trimestre, nos placentônios, a porcentagem média de células CD3+ foi 2,34\%; CD8+, 1,28\%; CD14+, 1,66\%; e CD335+, 0,96\%. Na região intercaruncular, a porcentagem de células CD3+ foi 0,71\%; CD8+, 1,63\%; CD14+, 2,81\%; e CD335+, 2,81\%. No segundo trimestre, os placentônios apresentaram 0,94\% de células CD3+; 0,77\% de CD8+; 0,72\% de CD14+e 0,51\% de CD335+. Na região intercaruncular, a porcentagem de células $\mathrm{CD} 3+$ foi $0,50 \%$; CD8+, 1,81\%; CD14+, 2,64\%; e CD335+, 0,51\%. No terceiro trimestre, os placentônios apresentaram 0,88\% de células marcadas CD3+; 0,66\% de CD8+; 1,06\% de CD14+e 0,74\% de CD335+. Na região intercaruncular, a porcentagem de células CD3+ foi 0,19\%; CD8+, 2,23\%; CD14+, 2,43\% e CD335+, 0,16\%. Os resultados mostraram que a imunomarcação de leucócitos na região do placentônio foi maior do que na região intercaruncular no terceiro trimestre. Concluiu-se que a população de leucócitos $\mathrm{CD} 3+$ e CD335+ na placenta bovina está reduzida, provavelmente devido à sua característica sindesmocorial. Essa característica representa uma barreira significante para o sistema imunológico da mãe, o que diminui drasticamente a exposição do concepto ao sistema de defesa da mãe.

Palavras-chave: Placentônio. Região intercaruncular. Imunologia. Tolerância materno-fetal. 
Correspondence to:

Thais Martins Chucri

Universidade de São Paulo, Faculdade de Medicina Veterinária,

Departamento de Cirurgia

Av. Prof. Dr. Orlando Marques de Paiva, 87

CEP 05508-000, São Paulo, SP, Brazil

e-mail: thaischucri@uol.com.br

Received: 16/4/2016

Approved: 12/5/2017

\section{Introduction}

The immune system plays an important role not only as a defense organ against external aggressions, but also as a mediator of the systemic balance. In spite of the wellknown importance of the immune system, some gaps still exist in the knowledge about pregnancy immunity. In this regard, maternal recognition of pregnancy involves detection of fetal antigens by the mother's immune system cells. This could be one of the possible mechanisms to avoid embryo rejection (SAFARANA et al., 2007; BENEDICTUS et al., 2015).

The uterine environment changes considerably from the moment of implantation to the moment of delivery. Leukocytes, hormones, interleukins, growth factors, and other proteins become present, favoring maternal immune tolerance (PICCINNI, 2003). The placenta plays a crucial role in the maintenance of pregnancy, as it is responsible for protection, nutrition, gas exchange, and endocrine control. Still, it has been used as a model for transplant immunology, because the fetus is a semiallogeneic tissue, i.e., it expresses both paternal and maternal genes (CHUCRI et al., 2010).

The placenta of ruminants is classified as zonary, polycotyledonary, and synepitheliochorial. It shows six tissue layers, which limit fetal and maternal circulation (MARQUES et al., 2007; CHUCRI et al., 2010; PETER, 2013). Bovine placenta is composed by maternal caruncles and fetal cotyledons. Together, these structures form the placentomes - the morpho-functional units of the placenta (PETER, 2013). An important difference between the immunogenicity of the intercaruncular region and the placentome is the expression of MHC class I, which is not expressed in the chorionic tissue of the placentome, whereas the intercaruncular region expresses MHC class I starting on the third quarter of pregnancy (DAVIES et al., 2004).

The presence of leukocytes in the placenta has been reported in different species, including men, sheep, cattle, and mice. In bovine placenta, leukocytes were found at the beginning and by the end of pregnancy. Larger amounts of these cells were observed in the intercaruncular region than in the placentome (OLIVEIRA; HANSEN, 2008). Among these cells, lymphocytes and macrophages are the most common cells involved in maternal-fetal tolerance (OLIVEIRA et al., 2012). During pregnancy, maternal leukocytes have their functional activity altered. Thus, their function in the uterus is different than in the rest of the body of the mother, leading to temporary tolerance to fetal antigens. This phenomenon is called split immune tolerance (MESTRE et al., 2010).

In humans, $\mathrm{T}$ cells are the most prevalent lymphocytes in women's endometrium and they participate in the implantation and maintenance of gestation, in synthesizing cytokines, and in regulating immunity (TILBURGS et al., 2008). Although a few studies evaluated the function of T cells in cows throughout pregnancy, Ohta et al. (2013) showed that the number of cells decreased as gestation progressed. On the other hand, the same authors showed that in the caruncle region, $\mathrm{T}$ cells were not observed. These authors suggested that $\mathrm{T}$-cell distribution might contribute to embryo implantation and remodeling of endometrial tissue, being closely involved in the maintenance of bovine gestation.

Another important leukocyte for the embryo development is the macrophage. These cells are important for antigen presentation (SCHLAFER et al., 2000) and apoptosis regulation, which may be deleterious for the embryo (ABRAHAMS et al., 2004). It was shown that macrophages secrete cytokines that modulate the maternal immune system, support pregnancy, and are responsible for embryonic development in cows (MANSOURIATTIA et al., 2012). Decreased activity of these cells by the end of pregnancy is associated with cases of retained placenta in bovines (MIYOSHI et al., 2002; MIYOSHI; SAWAMUKAI, 2004).

The main function of the natural killer cells is to eliminate cells that lack self-markers by their cytotoxic activity. According to Boysen and Storset (2009) their role during pregnancy is controversial, but they appear to be involved in remodeling the vascular tissue during the implantation of the fetus and also following fetal death. As reviewed by these same authors, the natural killer cells may participate in the immunological protection against uterine infections by means of their cytotoxicity and cytokineproducing abilities. 
Once leukocytes, mainly lymphocytes and macrophages, have an active role in maternal-fetal tolerance, immunophenotyping of these cells needs to be explored. Based on that, the aim of the present study was to identify the population of T lymphocytes (CD3+ and $\mathrm{CD} 8+)$, macrophages (CD14+), and natural killer cells $(\mathrm{CD} 335+)$ in the placentome and intercaruncular regions of bovine placenta.

\section{Materials and Methods}

\section{Animals}

Placentas were collected from a slaughterhouse. Placentomes and intercaruncular regions of cows at the different quarters of pregnancy (first, second, and third) were collected from a total of 15 animals. The period of pregnancy was estimated according to the measures described by Nodenand and Lahunta, 1990. The Bioethics Committee of the Faculty of Veterinary Medicine and Animal Science of the Universidade de São Paulo approved the study.

\section{Collection and preparation of tissue samples}

Placentomes and intercaruncular regions were collected systematically and randomly, according to stereology principles (STERIO, 1984). After uterus was removed from the abdominal cavity, it was incised in the avascular region and placed on the laboratory bench. A test system made up by orthogonal lines was randomly placed on the pregnant horn. A number between 1 and 8 was randomly drawn, and sampling was carried out in one $1 / 8$ fraction $\left(f_{1}\right)$.

As animals during the first quarter of pregnancy (mean of 40 days) may not have the placentome - a structure formed after about 60 days of pregnancy in cows - the intercaruncular region was used to represent the maternal portion of the sample, and the chorionallantoic membrane was used to represent the fetal portion.

Tissue samples were washed with PBS $0.1 \mathrm{M}$, placed in sterile plastic bags with the same solution, and taken to the laboratory under refrigeration.

\section{Flow cytometry}

Flow cytometry showed the percentage of positive cells, the expression of CD3+, CD8+ CD14+, and CD335+. In order to do that, placentomes and intercaruncular regions were washed in PBS $0.1 \mathrm{M}$ and separated by mechanical and enzymatic methods. In the mechanical separation procedure, fragments of placentomes were placed in a 150mesh steel wire mesh screen. A $1 \mathrm{~mL}$ syringe and culture medium (D-MEM) with $10 \%$ of bovine fetal serum and antibiotics were used. Fragments were pressed against the mesh for cell separation. In the enzymatic separation process, the intercaruncular region was broken into small fragments and immersed in $20 \mathrm{~mL}$ of trypsin $0.25 \%$ (LGC Biotecnologia ${ }^{\circledR}$, Cotia, Brazil) for 30 minutes in a water bath at $37^{\circ} \mathrm{C}$, under stirring. Then, fragments were gently pressed against the 150-mesh steel wire mesh screen for cell separation.

Cell suspension obtained from both regions was resuspended in a known volume of D-MEM with $10 \%$ of bovine fetal serum, and centrifuged ( $400 \mathrm{~g}$ for 8 minutes at $4^{\circ} \mathrm{C}$ ). After centrifugation, the medium was removed and cells were suspended in $30 \mathrm{~mL}$ of culture medium. In this phase, cell suspensions from intercaruncular regions were lysed with $\mathrm{NaCl} 0.2 \%$. After 20 seconds, $\mathrm{NaCl} 1.6 \%$ was added to this suspension. The next step was to count cells stained with Tripan Blue in a Neubauer chamber. For this procedure, a $20 \mu \mathrm{L}$ aliquot was collected and mixed with the stain, and then viable cells were counted.

After that, cell suspensions were washed once more in a centrifuge at $200 \mathrm{~g}$ for 5 minutes at $4^{\circ} \mathrm{C}$, and their concentration was adjusted to around $2 \times 10^{6}$ cells. Then, cells were placed in a FACS tube and incubated for 30 minutes with $1 \mu \mathrm{L}$ of primary monoclonal mouse anti-bovine antibody anti-CD3, anti-CD8, anti-CD14 (VRMD ${ }^{\circ}$, WA, USA), and anti-CD335 (AbDSerotec ${ }^{\circledR}$, GE, UK).

After this incubation period, cells were washed twice with PBS $0.1 \mathrm{M}$ and incubated again for 30 minutes, away from light, with $1 \mu \mathrm{L}$ of secondary goat anti-mouse antibody labeled with fluorescein (diluted 1:100 in PBS $0.1 \mathrm{M}, \mathrm{pH}$ 7.4). Cells were washed twice in PBS 0.1 M and analyzed in a BD FACScalibur flow cytometer (BD Biosciences ${ }^{\oplus}$, CA, USA).

Negative controls were used in each trial. The same concentration of $2 \times 10^{6}$ cells was transferred to two FACS tubes, and labeled "only cells" and "cells + secondary antibody". These tubes were analyzed for possible autofluorescence and unspecific bonds between secondary antibodies and the background.

The use of positive controls for the antibodies followed the same protocol as the one for the suspension of placenta cells, and were based on samples of peripheral bovine blood. 
One hundred thousand events of each sample were collected in Cell Quest Pro (BD Biosciences ${ }^{\circledR}$ ). The two cell types (lymphocytes and macrophages) were identified according to their Forward Scatter Channel (FSC) and Side Scatter Channel (SSC characteristics, which evaluated the size and internal complexity of each cell, respectively).

\section{Statistical analysis}

The descriptive analysis was performed by the arithmetic mean and the standard error of the mean. Also, inferential statistical analysis was performed to compare cell distribution among the first, second, and third trimesters of gestation. In spite of the small sample size, the Kolgomorov-Smirnov test demonstrated a normal distribution $(\alpha=0,05)$. Thus, the parametric Student's T-test and one-way ANOVA with repeated measures tests were chosen. All tests were conducted using the free software SPSS v. 17.0. Results were considered statistically significant when $\mathrm{P} \leq 0.05$.

\section{Results}

\section{Flow cytometry}

Cell viability was about $50 \%$ for placentomes and $95 \%$ for the intercaruncular region. In peripheral blood, where positive controls for antibodies were carried out, mean of positive cells was $5.09 \%$ for $\mathrm{CD} 3+$; $4.81 \%$ for $\mathrm{CD} 8+; 3.38 \%$ for CD14+; and 1.03\% for CD335+. Cell viability was about $85 \%$, and may be seen in Figure 1.

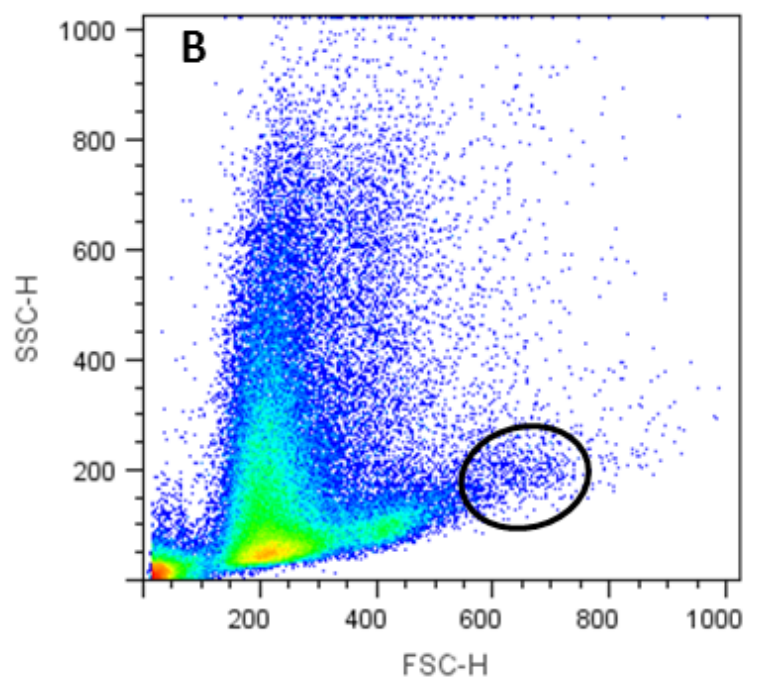

Figure 1 - The circled areas show the density plot gated for the lymphocyte region of bovine peripheral blood (A) and density plot gated for the monocyte region of bovine peripheral blood (B)

\section{CD3+, CD8+, CD14+ and CD335+ expression in placentomes}

The most frequent leukocytes and most expressed in the first quarter were lymphocytes CD8+ and CD3+. The mean of positive cells in this quarter was $2.34 \%$ for $\mathrm{CD} 3+(\mathrm{SE}=1.59) ; 1.28 \%$ for $\mathrm{CD} 8+(\mathrm{SE}=0.68) ; 1.65 \%$ for $\mathrm{CD} 14+(\mathrm{SE}=0.74)$; and $0.96 \%$ for CD335+ $(\mathrm{SE}=0.48)$. The results for the second quarter were partially similar to those of the first quarter, when we observed a greater frequency of lymphocytes CD3+ and CD8+. The mean of positive cells was $0.94 \%$ for $\mathrm{CD} 3+$ and 0.77 for CD8+ (SE $=0.08 / 0.14$, respectively $) ; 0.72 \%$ for $\mathrm{CD} 14+(\mathrm{SE}=0.14)$; and $0.85 \%$ for $\mathrm{CD} 335+(\mathrm{SE}=0.43)$. However, different from what was observed in the first two quarters, in the third quarter the most frequent cells were the CD14+, followed by CD335+, CD8+, and CD3+, the latter with the lowest labeling in this quarter. During the last quarter, the mean of positive cells was $0.88 \%$ for $\mathrm{CD} 3+(\mathrm{SE}=0.04) ; 0.66 \%$ for $\mathrm{CD} 8+(\mathrm{SE}=0.27) ; 1.06 \%$ for $\mathrm{CD} 14+(\mathrm{SE}=0.21)$; and $0.74 \%$ for $\mathrm{CD} 335+(\mathrm{SE}=0.14)$.

Comparing the distribution of the leukocytes throughout the progression of pregnancy, ANOVA with repeated measures did not show significant differences amongst the trimesters. The percentage of positive leukocytes (CD3+, CD8+, CD14+ and CD335+) in the placentome region are shown in Figure 2. 
$1^{\text {st }}$ trimester

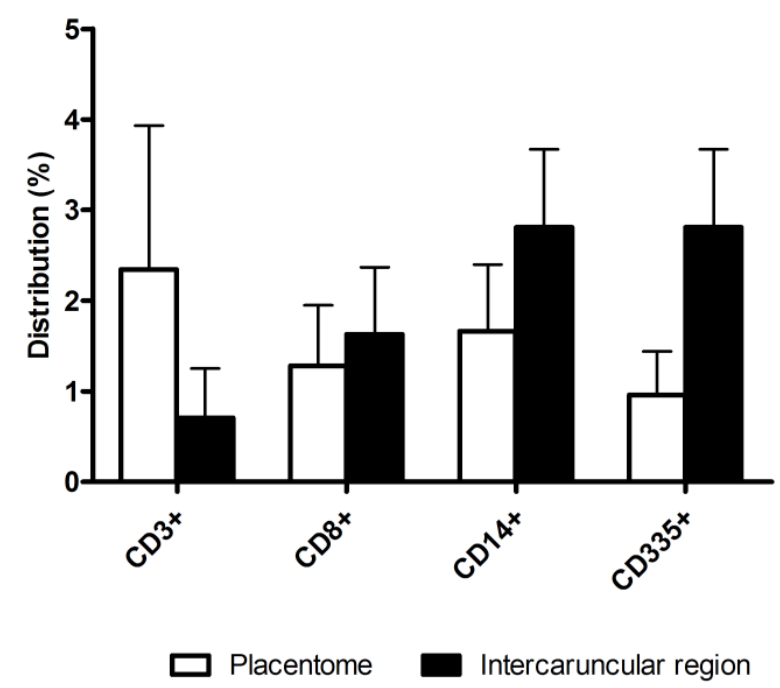

$2^{\text {nd }}$ trimester

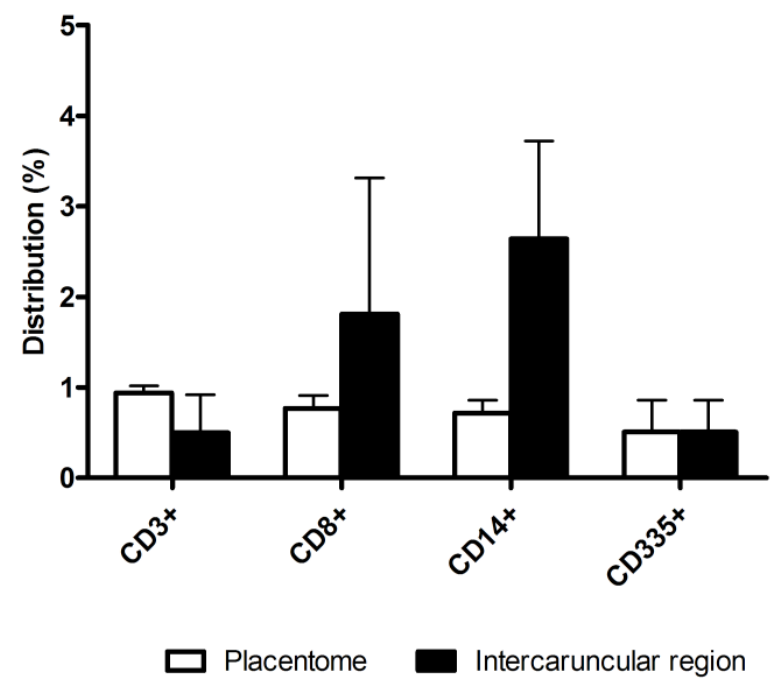

$3^{\text {rd }}$ trimester

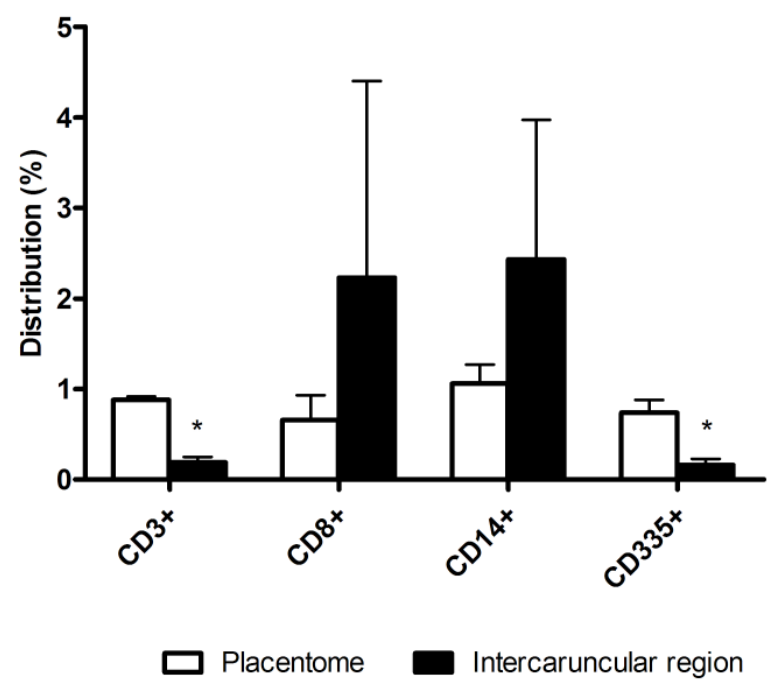

Figure 2 - Percentage of positive leukocytes (CD3+, CD8+, CD14+, and CD335+) in placentome and intercaruncular regions during the first $(\mathrm{A})$, second $(\mathrm{B})$, and third $(\mathrm{C})$ trimesters. ${ }^{*} \mathrm{p}<0.05$ compared to the same leukocyte type in the placentome (Student's T-test)

\section{CD3+, CD8+, CD14+ and CD335+ expression in the intercaruncular region}

In the intercaruncular region during the first quarter the most frequent cells were the CD14+ followed by the CD8+ cells. At this moment, the mean of positive cells was $0.71 \%$ for $\mathrm{CD} 3+(\mathrm{SE}=0.54) ; 1.63 \%$ for CD8+ $(\mathrm{SE}=0.74) ; 2.81 \%$ for $\mathrm{CD} 14+(\mathrm{SE}=0.86)$; and $0.62 \%$ for $\mathrm{CD} 335+(\mathrm{SE}=0.36)$. During the second trimester, mean of positive cells was $0.50 \%$ for $\mathrm{CD} 3+(\mathrm{SE}=0.42) ; 1.80 \%$ for $\mathrm{CD} 8+(\mathrm{SE}=1.50) ; 2.64 \%$ for $\mathrm{CD} 14+(\mathrm{SE}=1.08)$; and $0.51 \%$ for $\mathrm{CD} 335+(\mathrm{SE}=0.35)$. The mean of positive cells by the end of pregnancy in the intercaruncular region was $0.19 \%$ for $\mathrm{CD} 3+(\mathrm{SE}=0.06) ; 2.23 \%$ for $\mathrm{CD} 8+(\mathrm{SE}=2.17)$; $2.43 \%$ for $\mathrm{CD} 14+(\mathrm{SE}=1.54)$; and $0.16 \%$ for $\mathrm{CD} 335+$ $(\mathrm{SE}=0.07)$.
The percentage of positive leukocytes (CD3+, CD8+, $\mathrm{CD} 14+$, and $\mathrm{CD} 335+)$ in the intercaruncular region is demonstrated in figure 2. In the analysis of the intercaruncular region in the three quarters of pregnancy, similarly to what had been found in the placentome, ANOVA with repeated measures did not show significant differences.

\section{Placentome vs. intercaruncular region}

Comparing the two regions, the Student's T-test showed that the greatest amount of positive cells occurred in third quarter of pregnancy in the placentome. Specifically, there were significant differences in the number of CD3 $+[\mathrm{t}(4)=10.04$; $\mathrm{p}=0.001]$ and $\mathrm{CD} 335+[\mathrm{t}(4)=3.72 ; \mathrm{p}=0.02]$ distributions in the third trimester, which was decreased in the intercaruncular region compared to the placentome. 


\section{Discussion}

In bovines, expression of phenotyped leukocytes is lower if compared to other species, such as mice and humans. The main explanation may be the differences between the placentas of these species. Human placenta is deciduous, highly invasive, and few layers separate the mother from the fetus, enabling the constant passage of fetal antigens to the mother's circulation (LEISER; KAUFMANN, 1994; TRUNDLEY; MOFFETT, 2004). It represents a challenge to maternal immune system greater than to other animal species. Bovine placenta, on the other hand, has much less invasive implantation process (MARQUES et al., 2007), making it difficult for fetal antigens to be exposed to the mother's immune system.

Another explanation for the low expression of leukocytes in bovine placenta observed in this study may be the origin of the animals studied. Placenta samples were collected from a slaughterhouse, and the clinical history and health status of the animals was unknown. This is a problem since physiological conditions, such as stress, muscle activity, health status, temperature, altitude, nutritional status, mean age, breed (JAIN, 1986; KRAMER, 2000), and quarter of pregnancy (JAIN, 1993) directly affect the amount of leukocytes.

Comparing the results observed throughout the three pregnancy trimesters among the different leukocytes phenotypes and placental regions there were no significant differences with the exception of the CD3+ and CD335+ cells. Specifically, the frequency of those cells was greater in the placentome than in the intercaruncular region only in the third trimester. In the present work the lack of significant differences could be due to the small number of animals, as suggested by the clear trend towards an increase of CD8+ and CD14+ cells in the intercaruncular region. Thus, it could be suggested that an increase on sample size would show significant differences.

In this study, although not statistically significantly, there was a clear-cut trend towards an increase in the expression of all phenotyped leukocytes (CD3+, CD8+, CD14+, and $\mathrm{CD} 335+$ ) in the first quarter of pregnancy in relation to the other trimesters. Similarly, Oliveira and Hansen (2008) observed an increase in the number of lymphocytes at the beginning of pregnancy in cattle. Increased number of leukocytes (CD3+, $\mathrm{CD} 8+$, and $\mathrm{CD} 335+)$ at the beginning of pregnancy may be directly or indirectly related to the expression of receptors that mediate trophoblastic recognition and invasion (CHAOUAT et al., 2002; MOFFETT-KING, 2002; HANNA et al., 2006; RANGO et al., 2008), as well as production of cytokines that regulate and modulate maternal immune response and angiogenesis.

During implantation and decidualization in humans, lymphocytes make up about $20 \%$ of the cell population (WILCZYNSKI et al., 2002), with predominance of CD335+ in human and rodent placenta at the beginning of pregnancy (ASHKAR; CROY, 2001; ELAMI-SUZIN; MANKUTA, 2007). Several hypotheses related to potential functions of these cells are raised by detailed studies conducted in humans and mice, species that have hemochorial placentas (TAYADE et al., 2007). In this study bovines showed greater expression of CD335+ cells during the end of pregnancy. However, expression of these cells during the whole pregnancy was extremely low. This finding could be due to the fact that the amount of natural killer cells in bovine peripheral blood (about 2\% to 10\%) is also lower than that observed in humans (KAMPEN et al., 2006). High levels of natural killer cells in bovine blood have only been found during infections, mainly those caused by Neospora caninum (KLEVAR et al., 2007).

In this study, macrophages (CD14+) tended to be less expressed in the first quarter of pregnancy. In bovines, the role of these cells has not yet been established. However, at the beginning of pregnancy in humans, uterine macrophages have an important role in the regulation of apoptosis - a process that is deleterious to the development of the embryo (ABRAHAMS et al. 2004) - apart from favoring immunological tolerance to the fetus (HEIKKINEN et al., 2003) by means of the release of cytokines (SCHLAFER et al., 2000).

The second quarter of pregnancy showed a trend towards a decrease in the amount of all leukocytes in both regions compared to the first quarter. In humans, in the second quarter of pregnancy, maternal blood begins to perfuse intervillous spaces, enabling contact between maternal immune cells and fetal antigens (RILLEY, 2008).

In the third quarter of pregnancy, the expression of all leukocytes in bovine placenta seemed to be still lower than at the beginning of pregnancy. At this moment, CD14+ macrophages were the most common cells in the intercaruncular region and placentomes, similar to the findings of Oliveira and Hansen (2008), who showed that $\mathrm{CD} 14+$ cells were greater in the intercaruncular region than in placentomes. Furthermore, still in the third trimester, there was a significant decrease in the number of $\mathrm{CD} 3+$ and CD335+ cells in the intercarucular region when compared to the placentome. 
In bovines, macrophages were found at the beginning of pregnancy and became more frequent as pregnancy progressed (MIYOSHI; SAWAMUKAI, 2004; OLIVEIRA; HANSEN, 2008). The breed may have played an important role in this, which could explain this finding. In both studies cited above, researchers analyzed Hoslteins (Bos taurus), and not Zebu breeds (Bos indicus).

Miyoshi et al. (2002) stated that uterine macrophages of bovines showed strong acid phosphatase activity in normal pregnancies, but their enzymatic activity was less intense in cases of retained placenta. Thus, we may suggest that a decrease in the amount and/or activity of CD14+ cells at the end of pregnancy may be associated with episodes of retained placenta. However, collection of samples in slaughterhouses prevented this research from having information on the history of the animals.

In this study, lymphocytes seemed to decrease throughout the progression of pregnancy. According to Miyoshi et al. (2002) lymphocytes were found in small amounts in placentas of normal pregnancies. In cases of retained placentas, lymphocytes were found in the end of pregnancy. This suggests that the presence of lymphocytes in placenta does not have an important role in the predelivery period.

During the whole pregnancy, the intercaruncular region showed greater expression of leukocytes then the placentome, corroborating the data from Oliveira and Hansen (2008), who studied the expression of CD14+ and CD68+ cells in bovines. This finding may be due to the difference of immunogenicity between the intercaruncular region and the placentome, once chorionic tissue of the placentome does not express MHC class I during pregnancy, whereas the intercaruncular region expresses MHC class I starting on the third quarter of pregnancy (DAVIES et al., 2004). Besides, the intercaruncular region has a histological structure different from that of the placentome.

Structurally, intercaruncular regions are made up of glandular tissue found in the endometrium and in muscular tissue, i. e., in the myometrium and in blood vessels. Still, an agglomerate of lymphoid cells was found close to endometrial glands in the intercaruncular region (MARQUES et al., 2007). Acid phosphatase reaction was positive on the surface of the epithelium and in endometrial glands of the intercaruncular region of cows, demonstrating the possible phagocytic role of these structures (PEREIRA, 2004; MARQUES et al., 2007).

Although speculative, as a greater amount of all phenotyped leukocytes was observed in the intercaruncular tissue of bovines in particular CD14+ cells, it could be suggested that this region has functions related to protection of the fetus against the maternal immune response, as well as to the removal of cell debris and microorganisms of the uterus after parturition.

In this research there was a significant decrease of CD3+ (T lymphocytes) and CD335+ (natural killers) cells in the intercaruncular region throughout the end of pregnancy. This data corroborates other studies suggesting that the expression of those leukocytes decreases as gestation progresses (BOYSEN; STORSET, 2009; OHTA et al., 2013). Together, it strengthens the hypothesis that immune-cell distribution is related to the success and maintenance of bovine gestation. However, there are still several gaps on our knowledge about mechanisms of immunological adaptation during pregnancy, deserving further investigations.

\section{Acknowledgements}

The authors would like to thank the staff of the Departamento de Anatomia dos Animais Domésticos e Selvagens of the Universidade de São Paulo. Founding for this study was provided by Fundação de Amparo à Pesquisa do Estado de São Paulo (FAPESP) and Fundação Coordenação de Aperfeiçoamento de Pessoal de Nível Superior (CAPES); these sources had no further role in the design of the study; in the collection, analysis and interpretation of data; in writing the report, or in the decision to submit the paper for publication.

ASHKAR, A. A.; CROY, B. A. Functions of uterine natural killer cells are mediated by interferon gamma production during murine pregnancy. Seminars in Immunology, v. 13, n. 4, p. 235-241, 2001. doi: 10.1006/ smim.2000.0319. 
BENEDICTUS, L.; KOETS, A. P.; RUTTEN, V. P. The role of placental MHC class I expression in immune-assisted separation of the fetal membranes in cattle. Journal of Reproductive Immunology, v. 112, p. 11-19, 2015. doi: 10.1016/j.jri.2015.05.003.

BOYSEN, P.; STORSET, A. K. Bovine natural killer cells. Veterinary Immunology and Immunopathology, v. 130, n. 3-4, p. 163-177, 2009. doi: 10.1016/j.vetimm.2009.02.017.

CHAOUAT, G.; ZOURBAS, S.; OSTOJIC, S.; LAPPREEDELAGE, G.; DUBANCHET, S.; LEDEE, N.; MARTAL, J. A brief review of recent data on some cytokine expressions at the materno-foetal interface which might challenge the classical Th1/Th2 dichotomy. Journal of Reproductive Immunology, v. 53, n. 1-2, p. 241-256, 2002. doi: 10.1016/ S0165-0378(01)00119-X.

CHUCRI, T. M.; MONTEIRO, J. M.; LIMA, A. R.; SALVADORI, M. L.; KFOURY, J. R.; MIGLINO, M.A. A review of immune transfer by the placenta. Journal of Reproductive Immunology, v. 87, n. 1-2, p. 14-20, 2010. doi: 10.1016/j.jri.2010.08.062.

DAVIES, C. J.; HILL, J. R.; EDWARDS, J. L.; SCHRICK, F. N.; FISHER, P. J.; ELDRIDGE, J. A.; SCHLAFER, D. H. Major histocompatibility antigen expression on the bovine placenta: its relationship to abnormal pregnancies and retained placenta. Animal Reproduction Science, v. 8283, p. 267-280, 2004. doi: 10.1016/j.anireprosci.2004.05.016.

ELAMI-SUZIN, M.; MANKUTA, D. Role of natural killer cells in normal pregnancy and recurrent pregnancy loss. Harefuah, v. 146, n. 2, p. 140-144, 2007.

HANNA, J.; GOLDMAN-WOHL, D.; HAMANI, Y.; AVRAHAM, I.; GREENFIELD, C.; NATANSONYARON, S.; PRUS, D.; COHEN-DANIEL, L.; ARNON, T. I.; MANASTER, I.; GAZIT, R.; YUTKIN, V.; BENHARROCH, D.; PORGADOR, A.; KESHET, E.; YAGEL, S.; MANDELBOIM, O. Decidual NK cells regulate key developmental processes at the human fetalmaternal interface. Nature, v. 12, n. 9, p. 1065-1074, 2006. doi: 10.1038/nm1452.

HEIKKINEN, J.; MÖTTÖNEN, M.; KOMI J.; ALANEN, A.; LASSILA, O. Phenotypic characterization of human decidual macrophages. Clinical and Experimental Immunology, v. 131, n. 3, p. 498-505, 2003. doi: 10.1046/j.1365-2249.2003.02092.x.

JAIN, N. C. Essentials of veterinary hematology. Philadelphia: Lea \& Febiger, 1993.

JAIN, N. C. Schalm's veterinary hematology. 4. ed. Philadelphia: Lea \& Febiger, 1986.

KAMPEN, A. H.; OlSEN, I.; TOLLERSRUD, T.; STORSET, A. K.; LUND, A. Lymphocyte subpopulations and neutrophil function in calves during the first 6 months of life. Veterinary Immunology and Immunopathology, v. 113, n. 1-2, p. 53-63, 2006. doi: 10.1016/j.vetimm.2006.04.001.

KLEVAR, S.; KULBERG, S.; BOYSEN, P.; STORSET, A. K.; MOLDAL, T.; BJÖRKMAN, C.; OLSEN, I. Natural killer cells act as early responders in an experimental infection with Neospora caninum in calves. International Journal for Parasitology, v. 37, n. 3-4, p. 329-339, 2007. doi: 10.1016/j.ijpara.2006.11.002.

KRAMER, J. W. Normal hematology of cattle, sheep and goats. In: FELDMAN, B. F.; ZINKL, J. G.; JAIN, N. C. (Ed.). Schalm's veterinary hematology. Philadelphia: Lippincott Williams \& Wilkins, 2000. p. 1075-1084.

LEISER, R.; KAUFMANN, P. Placental structure: in a comparative aspect. Experimental and Clinical Endocrinology, v. 102, n. 3, p. 122-134, 1994. doi: 10.1055/ s-0029-1211275.

MANSOURI-ATTIA, N.; OLIVEIRA, L. J.; FORDE, N.; FAHEY, A. G.; BROWNE, J. A.; ROCHE, J. F.; SANDRA, O.; REINAUD, P.; LONERGAN, P.; FAIR, T. Pivotal role for monocytes/macrophages and dendritic cells in maternal immune response to the developing embryo in cattle. Biology of Reproduction, v. 87, n. 5, p. 123, 2012. doi: 10.1095/biolreprod.112.101121.

MARQUES, R. S.; VULCANO, M.; CAZERTA, S. M. M.; MIGLINO, M. A.; NETO, A. C. A.; PEREIRA, F. T. V. Caracterização morfológica da região intercaruncular uterina de vacas e búfalas gestantes. Biotemas, v. 20, n. 3, p. 103-114, 2007. 
MESTRE, A.; NORONHA, L.; WAGNER, B.; ANTCZAK, D. F. Split immunological tolerance to trophoblast. The International Journal of Developmental Biology, v. 54, n. 2-3, p. 445-455, 2010. doi: 10.1387/ijdb.082795ad.

MIYOSHI, M.; SAWAMUKAI, Y. Specific localization of macrophages in pregnant bovine caruncles. Reproduction in Domestic Animals (Zuchthygiene), v. 39, n. 3, p. 125128, 2004. doi: 10.1111/j.1439-0531.2004.00484.x.

MIYOSHI, M.; SAWAMUKAI, Y.; IWANAGA, T. Reduced phagocytotic activity of macrophages in the bovine retained placenta. Reproduction in Domestic Animals (Zuchthygiene), v. 37, n. 1, p. 53-56, 2002. doi: 10.1046/j.1439-0531.2002.00332.x.

MOFFETT-KING, A. Natural killer cells and pregnancy. Nature Reviews Immunology, v. 2, n. 9, p. 656-663, 2002. doi: 10.1038/nri886.

NODEN, D. M.; LAHUNTA, A. Embriologia de los animales domésticos: mecanismos de desarrollo y malformaciones. Zaragoza: Acribia, 1990. p. 341-347.

OHTA, T.; KOSHI, K.; USHIZAWA, K.; HOSOE, M.; TAKAHASHI, T.; YAMAGUCHI, T.; KIZAKI, K.; HASHIZUME, K. Dynamics of CD3' T-cell distribution throughout the estrous cycle and gestation in the bovine endometrium. The Journal of Reproduction and Development, v. 59, n. 6, p. 507-511, 2013. doi: 10.1262/ jrd.2012-200.

OLIVEIRA, L. J.; BARRETO, R. S.; PERECIN, F.; MANSOURI-ATTIA, N.; PEREIRA, F. T.; MEIRELLES, F. V. Modulation of maternal immune system during pregnancy in the cow. Reproduction in domestic animals (Zuchthygiene), v. 47, n. 4, p. 384-393, 2012. doi: 10.1111/j.1439-0531.2012.02102.x.

OLIVEIRA, L. J.; HANSEN, P. J. Deviations in populations of peripheral blood mononuclear cells and endometrial macrophages in the cow during pregnancy. Reproduction, v. 136, n. 4, p. 481-490, 2008. doi: 10.1530/ REP-08-0218.

PEREIRA, F. T. V. Eritrofagocitose placentária em búfalas (Bubalus bubalis bubalis - Simpson, 1945).
2004. 102 f. Tese (Doutorado em Ciências) - Faculdade de Medicina Veterinária e Zootecnia, Universidade de São Paulo, São Paulo, 2004.

PETER, A. T. Bovine placenta: a review on morphology, components, and defects from terminology and clinical perspectives. Theriogenology, v. 80, n. 7, p. 693-705, 2013. doi: 10.1016/j.theriogenology.2013.06.004.

PICCINNI, M. P. Role of immune cells in pregnancy. Autoimmunity, v. 36, n. 1, p. 1-4, 2003. doi: 10.1080/0891693031000067287.

RANGO, U. V. CLASSEN-LINKE, I.; KERTSCHANSKA, S.; KEMP, B.; BEIER BH. M. Effects of trophoblast invasion on the distribution of leukocytes in uterine and tubal implantation sites. Fertility and Sterility, v. 76, n. 1, p. 116-124, 2008. doi: 10.1016/S00150282(01)01859-3.

RILLEY, J. K. Trophoblast immune receptors in maternalfetal tolerance. Immunological Investigations, v. 37, n. 5, p. 395-426, 2008. doi: 10.1080/08820130802206066.

SAFARANA, S.; COELHO, R.; NEVES, A.; TRINDADE, J. C. Aspectos da imunologia da gravidez. Acta Médica Portuguesa, v. 20, p. 355-358, 2007.

SCHLAFER, D. H.; FISHER, P. J.; DAVIES, C. J. The bovine placenta before and after birth: placental development and function in health disease. Animal Reproduction Science, v. 60 , p. 145-160, 2000.

STERIO, D. C. The unbiased estimation of number and sizes of arbitrary particles using the dissector. Journal of Microscopy, v. 134, n. 2, p. 127-136, 1984. doi: 10.1111/ j.1365-2818.1984.tb02501.x.

TAYADE, C.; FANG, Y.; CROY, B. A. A review of gene expression in porcine endometrial lymphocytes, endothelium and trophoblast during pregnancy success and failure. The Journal of Reproduction and Development, v. 53, n. 3, p. 455-463, 2007. doi: 10.1262/ jrd.18170.

TILBURGS, T.; ROELEN, D. L.; VAN DER MAST, B. J.; DE GROOT-SWINGS, G. M.; KLEIJBURG, C.; SCHERJON, 
S. A.; CLAAS, F. H. Evidence for a selective migration of fetus-specific CD4+CD25bright regulatory $\mathrm{T}$ cells from the peripheral blood to the decidua in human pregnancy. Journal of Immunology, v. 180, n. 8, p. 5737-545, 2008. doi: 10.4049/jimmunol.180.8.5737.

TRUNDLEY, A.; MOFFETT, A. Human uterine leukocytes and pregnancy. Tissue Antigens, v. 63, n. 1, p. 1-12, 2004. doi: 10.1111/j.1399-0039.2004.00170.x.
WILCZYŃSKI, J. R.; TCHÓRZEWSKI, H.; BANASIK, M.; GLOWACKA, E.; WIECZOREK, A.; LEWKOWICZ, P.; MALINOWSKI, A.; SZPAKOWSKI, M.; ZEMAN, K. ; WILCZYNSSKI, J. Expression of intercellular adhesion molecule-1 on the surface of peripheral blood and decidual lymphocytes of women with pregnancyinduced hypertension. European Journal of Obstetrics, Gynecology, and Reproductive Biology, v. 102, n. 1, p. 1520, 2002. doi: 10.1016/S0301-2115(01)00550-4. 